\title{
近接場光学顕微鏡を用いたナノイメージング
}

\author{
齊藤 $\quad$ 結花 ${ }^{1} \cdot$ 馬越 貴之 ${ }^{2}$ \\ 1学習院大学理学部 画 171-0031 東京都豊島区目白 1-5-1 \\ ${ }^{2}$ 金沢大学理工学部 焉920-1192 石川県金沢市角間町
}

（2016 年 7 月 25 日受付；2016年 8 月 10 日掲載決定）

\section{Nano-imaging with Near-field Optical Microscope}

\author{
Yuika SAIтo $^{1}$ and Takayuki UmakoshI ${ }^{2}$ \\ ${ }^{1}$ Gakushuin University, 1-5-1 Mejiro, Toshima, Tokyo 171-0031 \\ ${ }^{2}$ Kanazawa University, Kakumamachi, Kanazawa, Ishikawa 920-1192
}

(Received July 25, 2016 ; Accepted August 10, 2016)

\begin{abstract}
Using near-field microscope, one can realize optical nano-imaging beyond the diffraction limit of incident light. The characteristic of this microscope is to combine variety of spectroscopic technique e. g. linear and non-linear vibrational spectroscopy, IR absorption, light scattering spectroscopy, fluorescence and photoluminescence. In this article, we will provide the basics of near-field microscope as well as reviewing recent 2-3 year's publications related to this technique.
\end{abstract}

KEYWORDS : near-field, tip-enhanced raman spectroscopy, nano-imaging

\section{1.は じめに}

ナノスケールの空間分解能で試料表面の化学イメージ ングが可能となれば, 微細構造が物性を決定する光電子 変換材料や, 多数の分子が関与する生物試料の観察に大 きな威力を発揮すると考えられる。近接場光学顕微鏡 は, 波としての光の回折限界に制限されていた空間分解 能の制限をとりのぞき， $10 \mathrm{~nm}$ オーダーの空間分解能 を実現することのできる画期的な顕微分光技術である。 赤外〜可視光を光源としているために, 常温常圧下で試 料に負荷をかけずに測定を行うことができる。同時に 様々な分光技術と組み合わせることができるのが，この 顕微分光の魅力でもある。ここでは近接場光学顕微鏡の 多様な測定方法の中でも, 近接場ラマン顕微鏡（Tipenhanced Raman spectrosopy : TERS）を中心に, 測定原 理と最新の研究成果について解説する。引用文献につい て, 完全に網羅すると相当数にのぼるため 2013 年以降 の論文を優先してとりあげた。近接場光学顕微鏡の基礎

E-mail : yuika.saito@gakushuin.ac.jp
については，たとえば参考文献 ${ }^{1)} に$ 詳細な記述がある。

\section{2. 近接場光学顕微鏡の測定方法}

近接場光学顕微鏡は Fig. 1 に示すように, 顕微分光光 学系と操作プローブ顕微鏡の両者を組み合わせたシステ ムである。空間分解能は対物レンズによる集光点のサイ ズではなくプローブ先端の大きさで決まるため, 原理的 にどこまでも空間分解能を高めることができるが，プロ ーブ先端の加工精度と感度による制限から 20〜30 nm が一般的である。プローブの種類によって二つのカテゴ リーが存在し, 光ファイバーに光をとおして微小開口か ら照射検出する開口型と, 先鋭な先端を持つ針をプロー ブとする非開口型である。開口型プローブは光のスルー プットを大きくすることが難しいので, 発光を伴う明る い分光：蛍光やフォトルミネッセンス（PL）測定に用 いられる。一方で非開口型は微弱光測光 : 線形および非 線形ラマン分光, 光散乱, 赤外 (IR) 吸収散乱分光など に用いられることが多い。最初に商品化された近接場光 学顕微鏡は開口型であるが，ここ2〜3 年非開口型も一 般ユーザー向けの商品として販売が開始されている。 


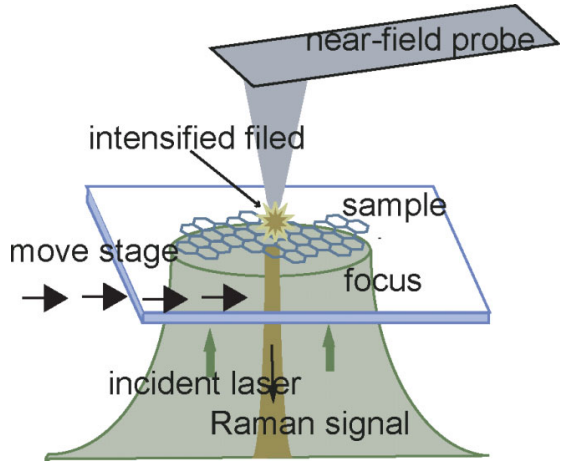

Fig. 1. (color online). Schematic view of near-field microscope : The system consists of scanning probe microscope and optical microscope. Near-field probe approached to the sample works as a nano-light source. The sample stage scans in $\mathrm{x}$ and $y$ directions synchronized with the optical measurements.

\section{1 走査プローブ顕微鏡}

プローブ顕微鏡として原子間力顕微鏡（AFM）また は走查トンネル顕微鏡（STM）のどちらを用いても， 近接場光学顕微鏡を構築することができる。しかし，分 光測定と同時に観測したい物性がある場合や，試料をの せるための基板が限定される場合にはどちらかに決まる ことになる。STM のトンネル電流がラマン分光に与え る影響について通常は問題にされないが, 空間分解能が 高まるにつれて議論の対象になることもある2,3)。

実験配置には, Fig. 2 に示す複数の型が存在する。 （a）配置は最も測定の容易な実験配置で，透明基板上に のせられた試料に対して下方から光を照射し信号光を検 出している。近接場プローブは上方からアプローチする ために両者が干渉することはなく，高い開口数（NA） で効率的な測光をすることができる。一方で試料をのせ ている基板が不透明なものであれば，必然的に（a）の 配置を諦めることになり，(b) または（c）配置を用い る。（b）配置の場合近接場プローブと対物レンズの配置 に空間的な制限があって, NA〜 0.7 程度が限界となって いる。また光の照射を妨げないように使用する近接場プ ローブにも制限がある。しかし半導体表面や，特殊な基 板上に作成した試料の観察が可能であるため, 近年報告 が増えているのは（b）配置である。(b) と同様に（c) 配置も基板の上半分のみを利用する形である。AFM の 設計自体も考虑する必要があって報告例は多くないが, いくつかのグループによって開発がすすめられている。 近接場光学顕微鏡で試料に印加される偏光は, プロー ブが偏光状態をかく乱するために入射偏光と同じにはな らないことが知られている。非開口型プローブの場合, 先端付近の一個の金属ナノ粒子の影響が支配的であると

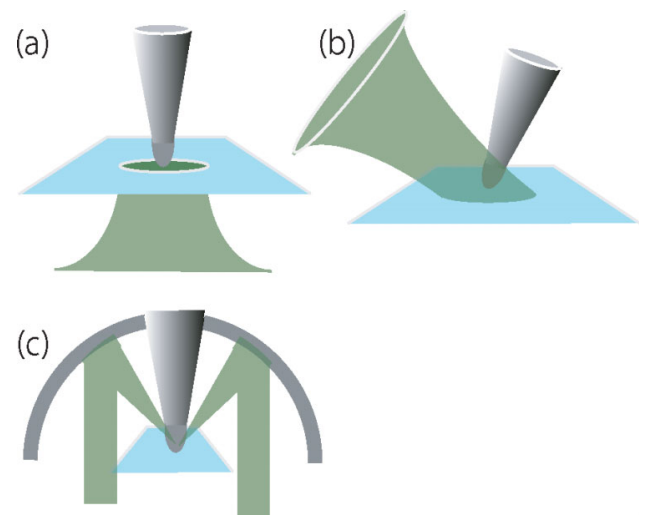

Fig. 2. (color online). Typical layouts of near-field microscope. (a) Transmission mode: the light pass through a transparent substrate. (b) Reflection mode : both probe and objective lens are placed above the sample. (c) Parabolic mirror type.

すると，このナノ粒子のつくるダイポールの向きを決定 することで近接場光の偏光を議論することができる4)。 ダイポールの極付近に近接した場所における電気力線の 向きを考えると, 近接場偏光を単一成分にすることは難 しく必ずいくつかの偏光成分の混合状態となる。プロー ブの形状が理想的な球形に近いほど, 入射偏光によって 自在に近接場プローブ先端に形成されるダイポールの向 きを制御することもできる。

\section{2 分光}

近接場光学顕微鏡は, 様々な分光法と組み合わせるこ とが可能だが，中でもラマン分光を用いた Tip-enhanced Raman Spectroscopy : TERS とよばれる手法が頻繁に用い られる。振動分光の一種であるラマン分光は, 分子の指 紋というほど分子構造に敏感で, 分析化学には大きな威 力を発揮する。また可視光域の単色連続レーザーを光源 としているため, 此較的安価で装置にも導入しやすい。 TERS の報告は 400 800 nm 領域の可視光によるものが 多いが，紫外光を用いた場合には，共鳴ラマン効果によ り特定の分子や電子状態を, 選択的に高い感度で観察す ることができて興味深い5)。

波長の短い紫外光を用いると原理的に顕微分光の空間 分解能は高くなるが，対物レンズなどの光学機器を作製 する材料の吸収や分散特性に問題が生じ，期待していた ほどの改善が見込めないので, 空間分解能がレンズに依 存しない紫外 TERS には期待が寄せられている。

ラマン散乱と同等の分子振動スペクトル情報を, IR 光の吸収を測定することで得ることができる。この原理 を利用して, IR 領域の光散乱効率を測定することで, 試料の持つ振動モードからの IR 散乱光をイメージング 


\section{第 12 号 (2016)}

する方法が開発され，Nano-IR と呼ばれている ${ }^{6}$ 。ラマ ン散乱という励起光源とは異なる波長を測定する TERS とは異なり, nano-IR では光源と同じ波長の散乱光が信 号光となるため, ロックイン検出によって SNを改善し 測定の信頼性を高めている7)。広带域 IR 光源とフーリ エ変換を同期させれば，スペクトル測定も可能であ $3^{8)}$ 。

\section{3. ナノ光源の形成}

ナノスケールの空間分解能を実現するためには，近接 場光を利用して照度が強く微小空間に局在化したナノ光 源を形成することが重要である。以下にナノ光源を作製 するいくつかの方法を示す。

\section{1 プラズモンーポラリトン}

光と金属中の自由電子の固有振動が結合（プラズモ ンーポラリトン) すると, 光の電場を局在化させ増強す ることができる。ここで得られる光電場の増強度は $10^{3}$ $\sim 10^{20}$ という值が報告されており, 微弱なラマン分光の 感度を高めるために用いられている。TERS は照度の強 いナノ光源を形成する必要から, プローブを自由電子金 属である金または銀でコーティングする。市販のシリコ ン製のプローブに金属コーティングする場合は，真空中 で抵抗加熱による蒸着で行うのが一般的だが, 蒸着面は しばしば平滑にならずに粒子状になる。蒸着速度を高め 同時に蒸着の立体的配置をかえたり, 板表面を改質した りすると,より平滑な金属面を作製することもでき る9)。化学エッチングで先鋭化した金属製の針を, 近接 場プローブとして用いることもできる。

効率的なプラズモン共鳴を得るためには，入射レーザ 一光の周波数と自由電子の固有振動が一致する必要があ る。具体的にはレーザーの波長に対して共鳴条件を満た すように，金属ナノ構造を変化させることになるが，近 接場光学顕微鏡の場合には空間分解能を保持したいの で, プローブ先端のサイズを大きく変化させることは望 ましくない。そのため, 先端径を変えずに感度を改善す るためのプローブデザインが提案されている。具体的に はプローブ全体を金属コーティングせずに先端から 〜 100 nm 程度まで金属のキャップをすると，プラズモ ン共鳴波長をチューニングさせることができる10,11)。ま た間隔を制御したナノ構造をプローブ先端に作製する と, 可視域にチューナブルな強い共鳴を得ることができ る $^{12,13)}$ 。計算機上でデザインされたプローブを実際に作 製するには, 精度の高い収束イオンビーム装置等を用い ることになり, 加工精度は最大 $5 \mathrm{~nm}$ 程度に制限され る。紫外光を用いた TERS では, 金や銀にかわってイン ジウムやアルミニウムが用いられる。
プラズモン共鳴周波数が，物質の種類によってどのよ うに変化するかを議論するために, バルク金属中の自由 電子の固有振動であるプラズマ周波数 $\omega_{\mathrm{p}}$ を考える。害 際の金属ナノ構造におけるプラズモン共鳴周波数は, $\omega_{\mathrm{p}}$ よりも長波長側に現れ, 形状に依存して複雑に変化 するので，ここでは $\omega_{\mathrm{p}}$ をプラズモン共鳴周波数の一つ の目安と考える。 $\omega_{\mathrm{p}}$ は以下の式で与えられる ${ }^{14)}$ 。

$$
\omega_{\mathrm{p}}^{2}=n e^{2} / m \varepsilon_{0}
$$

ここで $n$ は電子密度, $m$ は電子の有効質量, $\varepsilon_{0}$ は真空 の誘電率である。この式からわかるように電子密度と $\omega_{\mathrm{p}}$ の間には比例関係があるので, 可視域では共鳴周波 数を持たない物質がテラヘルッ領域でプラズモン特性を 示すことが考えられる。実際に,ドーピング密度を上げ たグラフェンのプラズモン特性が研究されている。グラ フェンはバンドギャップゼロの半導体または準金属であ り, 化学的方法やゲート電極からの電荷注入によりドー ピングレベルをあげることで, プラズマ周波数をギガへ ルッ帯まで近づけることができる ${ }^{15)}$ チューニングレン ジはいまのところテラヘルッ領域であるが, 減衰が小さ く長距離伝搬させることができるうえ加工しやすく, デ バイスやセンサーへの応用が期待されている。またグラ フェンを幅数十ナノメートル程度のリボン状にした物質 であるグラフェンナノリボンについても, 幅を変化させ ることによってプラズモン共鳴周波数を変調できること が報告されている ${ }^{16)}$ 。

\section{2 フォノンーポラリトン}

可視光が自由電子の固有振動と結合するように, エネ ルギーの低い赤外光は結晶中のフォノンと結合して, フ オノンーポラリトンを形成する。結晶の格子振動が起き る波長付近で, 誘電関数が分散型の曲線を示して誘電率 が負の值をとる波長域がある。この波長域では結晶の光 学特性が金属と類似の振る舞いを見せて入射光を強く反 射するので, フォノン-ポラリトンを誘起することがで きる。ここで議論している誘電関数の分散は, 特定のフ オノンモードに依存した現象であるから, 結晶軸によっ て誘電率に大きな異方性が生じることがある。たとえば 原子層化合物のような擬二次元構造を有する場合, 面内 方向に沿った誘電率の值が正で面外方向が負となること があり，このような条件下ではフォノンーポラリトンの 強い局在効果が観測される。フォノンーポラリトンはプ ラズモンーポラリトンより伝搬長が長くシャープな波長 依存性と高い電場局在効果を示すのが特徽で, 中赤外光 域において, データストレージ，コヒーレントな熱放 射, 波長可変光源, メタマテリアルなどへの応用が期待 されている ${ }^{17)}$ 。Raschke らは原子層物質 hexagonal boron nitride : hBN について，シンクロトロン放射 700〜5000 
$\mathrm{m}^{-1}$ を光源とした nano-IR の振幅位相解析を用いて，フ オノンポラリトンの観察を行い, 面内振動が面外振動フ オノンにくらべて強いフォノンーポラリトン結合を示す こと, また hBN の厚みを変えることでリニアに共鳴波 長を変調できることも示した ${ }^{18)}$ 。この実験結果は近接場 光学顕微鏡の一測定例ともいえるが, 同時にナノ構造化 したこれらの物質群と光の相互作用をうまく組み合わせ れば, 近接場光学顕微鏡のナノ光源としてフォノンーポ ラリトンを利用できることを示唆している。

\section{3 プラズモン・ナノフォーカス}

非開口型プローブはスループットの点で開口型のプロ ーブに対して勝っており, 様々な微弱光測光に利用でき るが，本質的にバックグランドの問題を抱えている。試 料が密集して存在している場合や, 十分に明るいナノ光 源が形成できない場合には, 測定の各点においてバック グランド信号を測定して混成信号から差し引く必要があ る。もし離れた場所で光励起を行ってこの励起を試料と の接点に誘導することができれば，バックグランドフリ 一の分光を実現することができる。プラズモンーポラリ トンを空間的に数ミクロン程度伝搬させて近接場光学に 利用する方法，すなわち “プラズモンナノフォーカス” が近年開発されている ${ }^{19)}$ 。プラズモン・ナノフォーカス を実現するためには, 光と自由電子を効率的に結合させ るための微細構造（プラズモンカプラー）と, 励起を伝 達し微小空間へ誘導する導波路としての平滑な金属表面 が必要である。Umakoshi らは Fig. 3 に示すように，プ ローブ先端から数ミクロンの位置にグレーティング構造

(a)

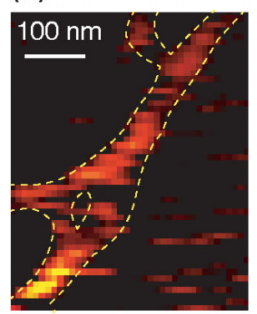

(b)

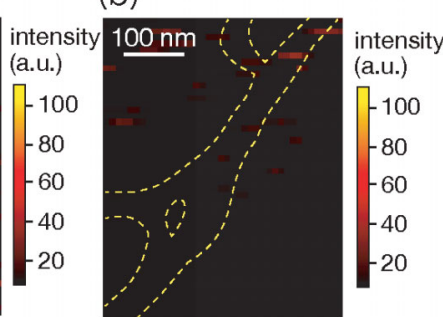

(c)

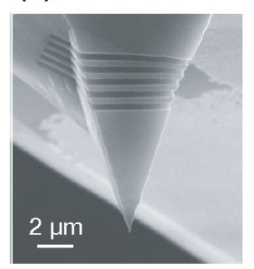

Fig. 3. (color online). (a) Near-field Rayleigh scattering image of carbon nanotubes by plasmon nano-focusing. (b) Plasmon coupling is off by changing the incident polarization.

(c) SEM image of a near-field probe with grating coupler.
を施してプラズモンカプラーとし, 先端に $642 \mathrm{~nm}$ のレ ーザー光を $30 \mathrm{~nm}$ ナノ光源に集光した。入射レーザー の偏光がこのグレーティングエッジに垂直な場合にプラ ズモンーポラリトンが励起される。このナノ光源を用い て, 実際にカーボンナノチューブについてバックグラン ドフリーのレーリー散乱光のイメージングを行った ${ }^{9)}$ 。 Fig. 3 (a) は励起偏光がグレーティングエッジに垂直, （b）は平行な場合である。（a）の場合には明瞭なナノチ ューブのコントラストが得られ, ナノ光源が形成されて いることが確認された一方で，（b）については光と電子 の結合がおこらず光源が形成されなかったことを示して いる。このことは, Fig. 3(a) のコントラストの由来 が, プラズモン・ナノフォーカスに由来することを示唆 している。

グレーティングを用いたプラズモンカプラーは最も基 本的な構造だが，ほかに可変ピッチ螺旋形の微小円錐型 プローブ20) 先端まで金をコーティングした光ファイバ ー ${ }^{21)}$ などもプラズモン・ナノフォーカスに利用されてい る。プラズモン・ナノフォーカスは, 吸収ロスによる伝 搬効率低下を防ぐために $600 \mathrm{~nm}$ 以上の長波長を用いる ことが多い。

\section{4. 近接場光学顕微鏡から見えるもの}

分析手法にはそれぞれ，測定対象に関して得意分野が ある。TERS は走査プローブ顕微鏡に依存しているので 表面分析を基本とし，ラマン分光が得意とする試料に関 する報告が多い。計測手法として近接場光学顕微鏡が未 熟であった 2000 年代はナノカーボンに関する報告が压 倒多数であったが, ここ最近は半導体, ポリマー材料, 生物試料など多種多様である。

新素材としてまた次世代ナノ・エレクトロニクス材料 の候補として注目を集めているナノカーボン系材料は強 いラマン信号光を発するため, TERS の開発当初から多 くの研究があった。最近でもカーボンナノチューブ，グ ラフェン, 酸化グラフェン, フラーレンの混合試料につ いて, 同じカーボン素材でありながら TERS を用いて分 子識別が容易であることが示され, 多数の研究者人口の あるナノカーボンの分野に, 解析手段としての TERS の 有用性がアピールされている ${ }^{22)}$ 。分子識別のみならず, 有機物残基や格子欠陷の分布の総合的なイメージングと なっていることも注目に値する。

グラフェンからはじまった原子層からなる物質群は, 平面六回対称性に起因する特異的な電子構造を利用した 高速電子デバイスの候補であり，同時に二次元構造に特 有の物性研究の対象として, 近年大きな注目を集めてい る。hBN や二硫化モリブデン $\left(\mathrm{MoS}_{2}\right)$, 二硫化タングス 
テン $\left(\mathrm{WS}_{2}\right)$, チタンセレン $\left(\mathrm{TiSe}_{2}\right)$ などの $\mathrm{MX}_{2}(\mathrm{M}=$ 遷移金属 $\mathrm{X}=6 \mathrm{~B}$ 族）物質について, TERS によるエッ ジの構造などの局所的な物性評価に期待がもたれてい $3^{23,24)}$ 。

結晶のフォノン振動数は格子に印加されたひずみの影 響を受けて変化するが，この変化はラマン分光を用いる と高感度に検出することができる。結晶中に離散的に分 布する欠陥分布も，ラマンスペクトルに現れる。格子歪 みや久陥は電子移動度に直接的な影響を与えるため, デ バイス設計の現場で強いニーズがある。代表的な半導体 材料であるひずみシリコンはこれまで TERS によるひず み分布評価が多数なされている。最近では化学エッチン グで作製したナノワイヤ・シリコンの歪曲ひずみの観測 が報告されている ${ }^{25)}$ 。半導体光電子変換材料について も, ナノ構造が変換効率に大きく関与してくる。固体面 発光デバイスとして開発されている InGaN/BaN 垂直ナ ノロッド量子井戸構造において, 構成要素の片析や境界 面での電荷の蓄積, 局所的なひずみの評価が TERS で分 析され, 作製過程の改善から最終的にはデバイス性能向 上に貢献することが示された ${ }^{26)}$ 。半導体ナノ材料は光励 起による電子ホールの再結合によるPL も物性の評価に 利用できるため, 開口型プローブによるナノイメージン グも報告されている。 $\mathrm{MoS}_{2}$ の PLナノイメージングで は, 境界から $150 \mathrm{~nm}$ 程度の領域において, エキシトン 消光が観察され, キャリアの移動度と再結合効率がエッ ジや欠陥の存在によって隇衰していることが明らかにな った ${ }^{27)}$ 。

生体分子系のように, 試料表面を構成している分子の 空間分布や分子間相互作用が複雑である場合は, ナノス ケールの空間分解能を持った分光手法が有効である ${ }^{28)}$ 。 最もシンプルな生細胞モデルとして水中に置かれた脂質 膜に関する研究が報告されてきた。水中 TERS は技術的 には十分に可能になっているが, 報告例としては未だ少

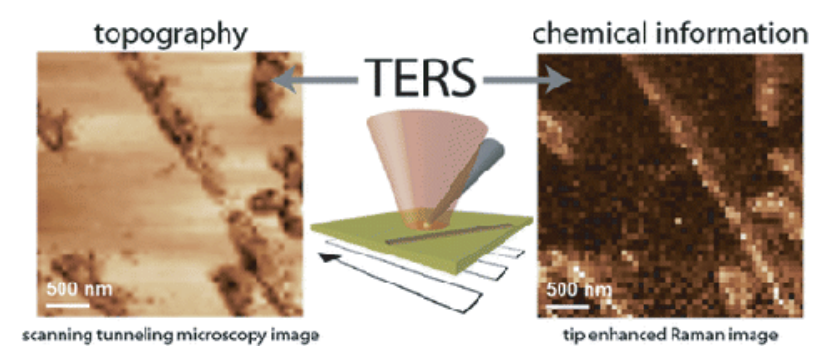

Fig. 4. (color online). TERS imaging of amyloid nanotape. Left : STM topographic image. Right: TERS imaged, the contrast is obtained by aromatic vibration. From Ref. 29) (C)2013 American Chemical Society.
数にとどまっており，むしろ空気中におけるバイオイメ ージングが精力的に行われている。Fig. 4 は Zenobi らの グループによって取得されたアミロイド・ナノテープの TERS イメージンングである ${ }^{29}$ 。本来は微弱な有機分子 からのラマン散乱光を, 金基板と銀プローブの構成する ギャップモードを利用して増強している。左は試料の形 状に対応した STM 画像, 右は $632 \mathrm{~nm}$ のレーザーを用 いた TERS 測定の結果からナノテープを構成するペプチ ド由来の芳香族環 $\left(1004 \mathrm{~cm}^{-1}\right)$ の強度を抽出してイメ ージングした。両者は類似の空間分布を示しているが, よく見ると光学像はやや細く真っすぐ繋がっているが, STM 像では明膫にあらわれていない箇所がある。この ことはナノテープが, すぐには特定できないが何らかの 未知の素材で覆われていることを示唆している。この成 果は現段階では一測定例にとどまっているが, プローブ 顕微鏡による形状像からは得ることのできないスペクト ル情報が空間の各点について格納されていることを考虑 すると, 近い将来バイオテクノロジーの強力なツールと なることが予想できる。

nano-IR によるナノイメージングの報告例は近年, 増 加しつつある。ナノイメージングにとどまらず，フェム トポンプ・プローブ時間分解測定を同時に実現し，100 フェムト〜 1ピ秒の時間スケールで $100 \mathrm{~nm}$ 以下の微 小領域で二酸化バナジウムのマイクロ・クリスタルの相 転移の観察 ${ }^{30)}$, 結晶性の異なる高分子試料ポリーテトラ フルオロエチレンについて局所的な振動緩和の測定の結 果が報告されている ${ }^{31) 。}$

\section{5. 最 後 に}

本稿は, 近接場光学顕微鏡の基礎を解説すると同時 に, 最近 2 3 年のナノイメージング技術の動向がわか るように作成した。近接場光学顕微鏡はこれまでプラズ モニクスの研究と歩調をあわせ, 可視光を用いた分光法 の役割が大きかったが, 最近はナノ光源の形成方法が多 岐にわたっており, 波長域が拡大しつつある。今後は表 面科学のための重要な分光技術として, ますます応用研 究が広がっていくことが期待される。

\section{謝 辞}

本稿の作成に関し石川篤博士に助言を頂きました。ま た, 執筆に誘って下さった青柳里果先生に感謝申し上げ ます。

\section{文献}

1) S. Kawata (Ed.) : "Topics in Applied Physics 81, Nearfield Optics and Surface Plasmon Polaritons” (Springer, 
2001).

2) R. Zhang, Y. Zhang, Z.C. Dong, S. Jiang, C. Zhang, L.G. Chen, L. Zhang, Y. Liao, J. Aizpurua, Y. Luo, J.L. Yang and J.G. Hou : Nature 498, 82 (2013).

3) C. Chen, N. Hayazawa and S. Kawata : Nat. Commun. 5, 3312 (2014).

4) T. Mino, Y. Saito and P. Verma : ACS Nano 8, 10187 (2014).

5) A. Taguchi, N. Hayazawa, K. Furusawa, H. Ishitobi and S. Kawata : J. Raman Spectrosc. 40, 1324 (2009).

6) E.A. Muller, B. Pollard and M.B. Raschke : J. Phys. Chem. Lett. 6, 1275 (2015).

7) O. Khatib, J.D. Wood, A.S. McLeod, M.D. Goldflam, M. Wagner, G.L. Damhorst, J.C. Koepke, G.P. Doidge, A. Rangarajan, R. Bashir, E. Pop, J.W. Lyding, M.H. Thiemens, F. Keilmann and D.N. Basov : ACS Nano 9, 7968 (2015).

8) L. Wang and X.G. Xu : Nat. Commun. 6, 8973 (2015).

9) T. Umakoshi, Y. Saito and P. Verma : Nanoscale 8, 5634 (2016).

10) T.L. Vasconcelos, B.S. Archanjo, B. Fragneaud, B.S. Oliveira, J. Riikonen, C. Li, D.S. Ribeiro, C. Rabelo, W.N. Rodrigues, A. Jorio, C.A. Achete and L.G. Cancado: ACS Nano 9, 6297 (2015).

11) I. Maouli, A. Taguchi, Y. Saito, S. Kawata and P. Verma : Appl. Phys. Experss 8032401 (2015).

12) T. Kim, K-S. Jeon, K. Heo, H.M. Kim, J. Park, Y.D. Suh and S. Hong: Analyst 138, 5588 (2013).

13) A. Taguchi, Jun Yu, P. Verma and S. Kawata : Nanoscale 7, 17424 (2015).

14) C.F. Bhren and D.R. Hoffman : "Absorption and scattering of light by small particles” (Wily, 1983).

15) S. Xiao, X. Zhu, B-H. Li and N.A. Mortensen : Front. Phys. 11, 117801 (2016).

16) I. Silveiro, J.M.P. Ortega and F.J.G. Abajo : Light : Science \& Applications 4, 241 (2015).

17) A.Y. Nikitin, E. Yoxall, M. Schnell, S. Vélez, I. Dolado, P. Alonso-Gonzalez, F. Casanova, L.E. Hueso and R. Hillenbrand : ACS Photo. 3, 924 (2016).

18) Z. Shi, H.A. Bechtel, S. Berweger, Y. Sun, Bo Zeng, C. Jin, H. Chang, M.C. Martin, M.B. Raschke and F. Wang : ACS Photo. 2, 790 (2015).
19) B.N. Tugchin, N. Janunts, A.E. Klein, M. Steinert, S. Fasold, S. Diziain, M. Sison, E.-B. Kley, A. Tünnermann and T. Pertsch : ACS Photo. 2, 1468 (2015).

20) D. Kuang, L. Dong and Y. Cao: Plasmonics 126, 185 (2016).

21) B.N. Tugchin, N. Janunts, A.E. Klein, M. Steinert, Stefan Fasold, S. Diziain, M. Sison, E-B. Kley, A. Tünnermann and T. Pertsch : ACS Photo. 2, 1468 (2015).

22) E. Sheremet, R.D. Rodriguez, A.L. Agapov, A.P. Sokolov, M. Hietschold and D.R.T. Zahn : Carbon 96, 588 (2016).

23) S.Z. Butler, S.M. Hollen, L. Cao, Y. Cui, J.A. Gupta, H.R. Gutiérrez, T.F. Heinz, S.S. Hong, J. Huang, A.F. Ismach, E. Johnston-Halperin, M. Kuno, V.V. Plashnitsa, R.D. Robinson, R.S. Ruoff, S. Salahuddin, J. Shan, L. Shi, M.G. Spencer, M. Terrones, W. Windl and J.E. Goldberger: ACS Nano 7, 2898 (2013).

24) D-S. Kim, H. Kwon, A. Yu. Nikitin, S. Ahn, L. MMoreno, F.J.G. Vidal, S. Ryu, H. Min and Z.H. Kim : ACS Nano 9, 6765 (2015).

25) N. Kazemi-Zanjani, E. Kergrene, L. Liu, T-K Sham and F. Lagugné-Labarthet: Sensors 13, 12744 (2013).

26) E. Poliani, M.R. Wagner, S. Reparaz, M. Mandl, M. Strassburg, X. Kong, A. Trampert, C.M. Sotomayor, Torres, A. Hoffmann and J. Maultzsch : Nano Lett. 13, 3205 (2013).

27) W. Bao, N.J. Borys, C. Ko, J. Suh, W. Fan, A. Thron, Y. Zhang, A. Buyanin, J. Zhang, S. Cabrini, P.D. Ashby, A. Weber-Bargioni, S. Tongay, S. Aloni, D.F. Ogletree, J. Wu, M.B. Salmeron and P.J. Schuck : Nat. Commun. 6, 7993 (2015).

28) E.A. Pozzi, M.D. Sonntag, N. Jiang, J.M. Klingsporn, M.C. Hersam and R.P. Van Duyne: ACS Nano 7, 885 (2013).

29) M. Paulite, C. Blum, T. Schmid, L. Opilik, K. Eyer, G.C. Walker and R. Zenobi : ACS Nano 7, 911 (2013).

30) S.A. Dönges, O. Khatib, B.T. O’Callahan, J.M. Atkin, J.H. Park, D. Cobden and M.B. Raschke : Nano Lett. 16, 3029 (2016).

31) J.M. Atkin, P.M. Sass, P.E. Teichen, J.D. Eaves and M.B. Raschke : J. Phys. Chem. Lett. 6, 4616 (2015). 